\title{
Study on the Employment-oriented Teaching Quality Management System of Higher Vocational Colleges
}

\author{
Zhe JI \\ Lanzhou Resources and Environment VOC-Tech College
}

\begin{abstract}
In this paper, the general idea and quality assurance for the teaching quality management system of higher vocational colleges are proposed. A teaching quality management system for higher vocational colleges is constructed and studied to help these schools clearly know the development ideas and accordingly improve the core school competitiveness, and eventually promote a continuous long-term development.
\end{abstract}

Keywords: Employment-orientation; Higher Vocational Colleges; Teaching Quality Management

\section{Introduction}

Higher vocational education, as an important part of higher education system, has trained and transported the front-line high quality application technical personnel with the competence of "production, construction, management and service" to the society. At present, it is particularly critical to comprehensively improve the educational and teaching quality of higher vocational colleges, provide the personnel meeting the social needs, and ensure graduates to get employed. As a result, the importance of quality management has been realized by increasing higher vocational colleges. IS09000 quality management system is a set of international standard internationally requiring a full-process, sound management in an organization, and it clearly shows quality management system is made up of organization, resources, process, measurement analysis and improvement, and other parts. Also, the basic requirements for the quality are raised in this standard. Practice has proved that the application of this system in the field of higher education, especially in higher vocational education, plays a significant effect on the improvement of education quality. Currently, the teaching quality management system in higher vocational colleges of China is not sound, and the management quality is not high, and thus, an effective connection between personnel training and market demand is difficult to form and subsequently the prospect for the employment of the graduates trained by higher vocational colleges is affected. Therefore, practically deepening the reform of higher vocational education under the orientation of employment and standardizing the management of higher vocational education and improve the quality of teaching management according to the requirements of the IS09000 quality management system are important ways to promote the sustained and healthy development of higher vocational education.

\section{The general idea of constructing a teaching quality management system for higher vocational colleges}

Quality has always been an important concern in the development of higher vocational education. How is the teaching and education quality ensured? Overall, the teaching quality management system of higher vocational colleges needs to be constructed according to the following model shown in Fig.1. 


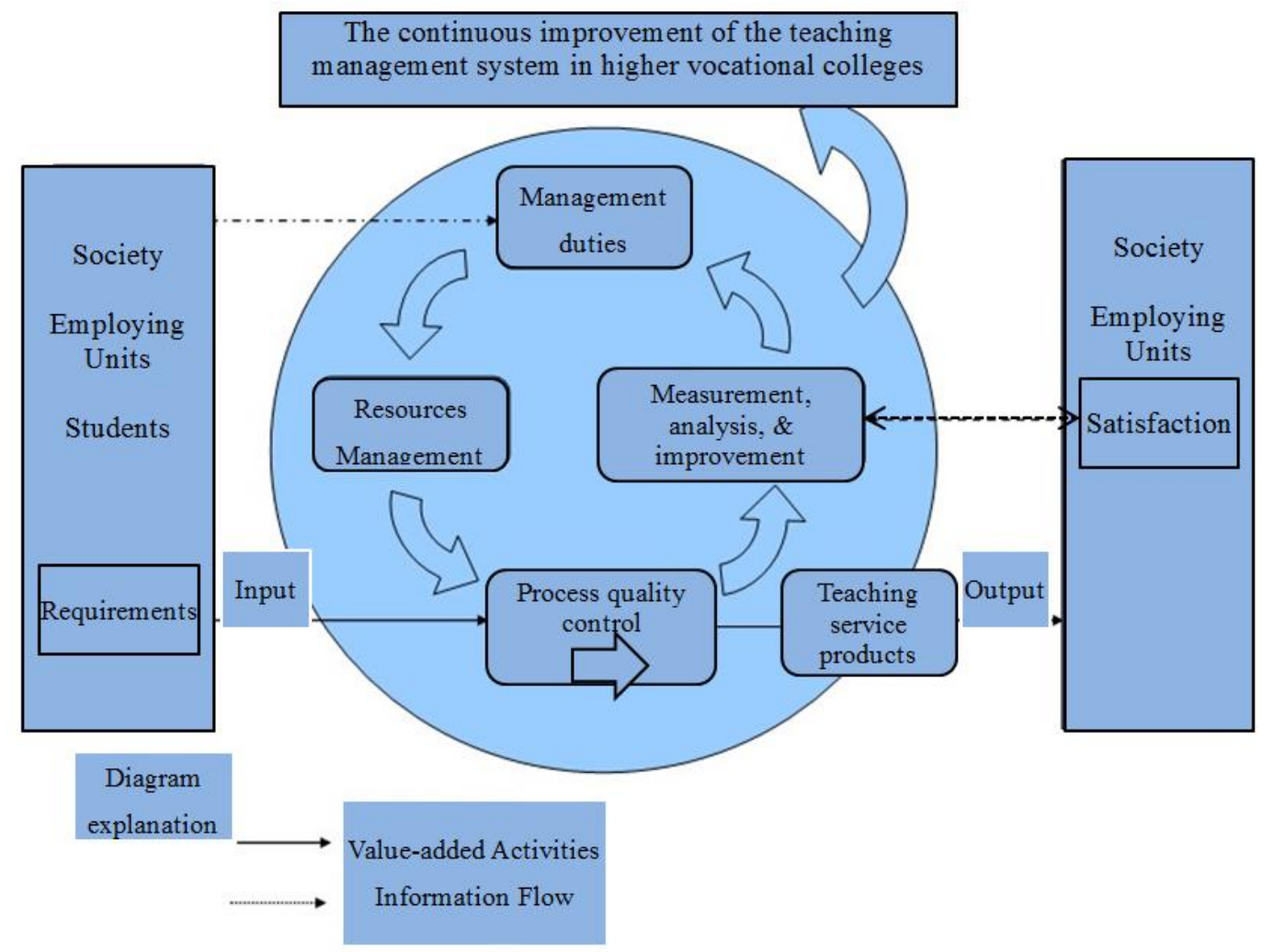

Fig.1 the model of constructing a teaching quality management system for higher vocational colleges under the orientation of employment

\subsection{Defining the guiding ideology for education}

First, educational idea and concept is necessarily defined, and a higher vocational college's level, area, and industrial position must be reasonably positioned, to assure the quality of higher vocational college. Service department, service regional economy, and service industries are supposed to form, aiming to cultivate the educational idea and concept of the personnel with application-oriented technologies.

Second, a reasonable major structure fit with the local economic and industrial structure, occupational structure and technical structure is necessarily established. In this way, the technical services and personnel support demanded by the economic and social development can be provided by higher vocational education, and this is also a requirement of China's higher education field and even the whole society for higher vocational colleges.

Third, the skilled talents training flow and personnel quality evaluation standard conforming to the characteristics of higher vocational education are necessarily formed. That is to say, the creative development of curriculum system and the establishment of practice and training conditions for the combination of production, study and research are demanded on the basis of major groups system.

Fourth, teaching elements such as faculty, experimental training conditions, practice bases, and technical conditions of teaching are necessary conditions for assuring teaching quality, of which faculty and experimental training conditions are the core conditions forming the teaching quality. 


\subsection{Building a scientific teaching quality management system}

Building a scientific teaching quality management system can be a factor of the above conditions, but it is vital to ensure the education and teaching quality. In general, the following aspects are necessarily contained in a scientific quality management system.

\subsubsection{Leader's awareness}

Seen from the general rules of management, leader's awareness plays a decisive role in the management situation and level, and thus, leaders in higher vocational colleges are required to possess a strong sense of social responsibility and play a leadership role based on the spirit responsible for society and school, aiming to implement organizational quality management.

\subsubsection{Advanced scientific management theory}

The scientific cognition and advanced management idea in higher vocational education are the foundations for the quality management theory in higher vocational colleges.

\subsubsection{Appropriate management model}

The quality management and management model of higher vocational colleges are necessarily determined and implemented in combination with the actual school conditions.

2.2.4 The quality management system of higher vocational colleges is often ignored

The teaching management team of many schools is composed of the management personnel chosen directly from teachers or from administrative personnel.

Generally speaking, the establishment and operation of quality management system are the main aspects of the quality assurance in higher vocational colleges, and these must be regarded by the administrative authorities of higher vocational colleges as main tasks to stress.

\section{Building a teaching quality assurance system oriented at employment}

\subsection{Assurance for faculty}

To better solve the above mentioned problems, an enhancement to the construction of faculty and providing faculty assurance for the teaching quality are necessary. Thus, the following aspects have to be focused. First, strengthening the construction of faculty training in higher vocational colleges and establishing a system for the exchange between higher vocational teachers and industrial or enterprise technical personnel are necessarily implemented. Teachers are arranged to receive learning and skills training at training bases; teachers, who are with ability and have potential, are encouraged to communicate with the front-line production personnel, so as to develop into real "double quality" teachers. Second, widening the channels of attracting higher vocational teachers, hiring the practically experienced part-time teachers from companies to give students lectures, improving part-time teachers introduction mechanism, establishing part-time teachers compensation system, and implementing an open teachers training system are musts. Third, the higher vocational faculty training model should be actively explored and made. Fourth, teachers' theoretical level and professional quality are improved through continuous learning. Fifth, special professional title evaluation standards are established for higher vocational teachers, and simultaneously the professional title evaluation and employment system are necessarily changed.

\subsection{Assurance for the construction of major management and major teaching resources}

School's major arrangement management refers to a process of major setting-up and adjustment under the guidance of the major directories issued by the state and local departments. The construction of major teaching resources is the most important teaching basics construction, and 
the key point to improve the major construction level and personnel training quality. Therefore, the construction of major management and major teaching resources must be assured from several aspects as follows. First, the construction of the teaching resources for excellent courses must be assured. The construction of the excellent courses in higher vocational colleges is an important part of teaching quality and teaching reform project, and these courses are often demonstrations oriented at higher vocational colleges for the purpose of manifesting the requirements of high-tech personnel training. Second, the construction of the teaching resources for the key majors in the state's important colleges must be assured. The ultimate purpose of the above is to improve $\mathrm{LZH}$ College's teaching resources design, construction competence and course design capability, and accumulate a great number of outstanding, distinguishing teaching resources.

\subsection{Assurance for hardware}

As the "popularization" of higher education is promoted in recent years, the construction of hardware facilities has been constantly enlarged by LZH College, to meet the continuously expanded enrollment. Under the effect of the objective factors such as local policy, the contradiction between budget shortage and unceasingly expanded enrollment is exposed, and also a lot of difficulties exist in the construction of infrastructure. Thus, higher vocational colleges are required to actively cooperate with enterprises and increase the investment and financing projects, so as to increase the construction of school hardware facilities.

\subsection{Assurance for practice and training bases}

Practice and training bases are divided into two types: campus bases and off-campus bases. Campus bases refer to the practice and training bases constructed for the simulation of the real situation in campuses; off-campus bases mainly refer to the practice and training bases constructed jointly by school and enterprises outside campuses under the school-enterprise cooperation and different major or industrial conditions.

In campus bases, a real professional environment is primarily created. In this aspect, 84 experiment training rooms have been established by LZH College, belonging to mining practice technology center, geological exploration technology training center, meteorological training center, environmental technology training center. mechanical and electrical technology training center, safety engineering training center, measurement technology training center, and information technology training center, respectively. The modern simulation mine is a locally shared training base built jointly by the ministry of education, the ministry of finance, and Gansu Province, which is the only simulation mine base in China's institutions of higher learning and was listed by the ministry of land and resources in the first list of the national science education bases in May 2009. Electrical and electronic training room is a vocational education construction project supported by the ministry of education and the ministry of financed. Meteorological training center is a practice base supported by China's Meteorological Administration. Mine surveying and coal chemical center is a training base supported by the financial department of Gansu province.

The construction and development of off-campus bases are closely linked with school-enterprise cooperation. The construction of off-campus bases is a process of extending and improving campus practice teaching for making a "zero distance" exist between students and professional posts. Thus, the professional skills of students are trained when the theories are consolidated, so as to comprehensively improve the quality. Students can be placed in a completely real work environment to carry out post practice and field training, and all practices can be implemented strictly in accordance with 
industrial standards and enterprise requirements. Training bases may have a close tie with the future jobs of students. Off-campus bases are not only the platforms for training students' practical ability, but also functional places for schools to carry out the education and teaching reform, scientific research, social service, employment guidance, and so on.

\section{Conclusion}

To deepen the reform of higher vocational education and develop characteristic higher vocational colleges, more and more schools come to realize the inevitable trend of "combination of learning with production and school-enterprise cooperation", and this is a reflection to the higher vocational education oriented at employment. Currently, the funds allocation is in shortage for higher vocational education, thus forcing schools to actively explore ways and means of school-enterprise cooperation. Then, higher vocational education can better develop. Special care is necessary to receive from all walks of life to higher vocational colleges, so as to strengthen the cooperation with higher vocational colleges and realize resources sharing.

\section{References}

[1] Shuchao MA, Wei FAN. Higher Vocational Education-Ten Years of Laying a Foundation for the Regional Harmonious Development $[\mathrm{J}]$. China's Higher Education, 2012 (18)

[2] Jun ZHU, Meizhen CHENG. The Application of ISO9000 Series standards in the Management of Teaching Quality in Colleges and Universities [J]. Journal of Education, 2008 (10).

[3] Guangming FENG. Undergraduate Educational Quality Management System based on ISO9000 Series Standards and Its Operation [J]. Occupational Circle, 2007 (14).

[4] Qimao CAI, Meihua YUAN. Exploration on the Implementation of ISO9000 Series Standards in Higher Vocational Education [J]. Occupational Circle, 2007 (6). 